\title{
Liquidity Analysis Using Cash Flow Ratios as Compared to Traditional Ratios in the Pharmaceutical Sector in Jordan
}

\author{
Sulayman H. Atieh ${ }^{1}$ \\ 1 Accounting Department, College of Finance \& business, The World Islamic Science \& Education University, \\ Amman, Jordan \\ Correspondence: Dr. Sulayman H. Atieh, Associate Professor of Accounting, Accounting Department, College of \\ Finance \& Business, The World Islamic Science \& Education University, Amman, Jordan. E-mail: \\ sulaiman.atieh@gmail.com \\ Received: March 2, 2014 \\ Accepted: April 1, $2014 \quad$ Online Published: June 18, 2014 \\ doi:10.5430/ijfr.v5n3p146 \\ URL: http://dx.doi.org/10.5430/ijfr.v5n3p146
}

\begin{abstract}
The purpose of this study is to examine the liquidity position of the Jordanian pharmaceutical sector using the traditional ratios as compared to the more recently developed cash flow ratios.

The research involved the comparison between traditional ratios and cash flow ratios of the big seven companies of the pharmaceutical industry in Jordan over six years period (2007-2012). The companies were all from the same sector, and the data was obtained from the annual reports of these companies.

The findings of the study revealed the following:

- There are differences between the traditional ratios which relied heavily on the values derived from balance sheet, and cash flow ratios which relied heavily on values derived from statement of cash flows.

- A conclusion on the liquidity of the company based only on traditional ratios could lead to incorrect decisions.

- Analysis based on traditional ratios should be compared with cash flow ratios before reaching any conclusion regarding financial liquidity position.

- The study showed that there were examples of companies that had good traditional ratios. While their cash flow ratios were weak. In contrast, there were also companies that had poor traditional ratios, but the cash flow ratios showed a better liquidity position. The cash flow ratios provide more information than traditional ratios in measuring the liquidity position of the company. As a result of testing the study hypotheses, and applying SPSS, the significant differences between the cash flow ratios and traditional ratios are determined to measure the liquidity of the Jordanian pharmaceutical Companies.
\end{abstract}

Keywords: liquidity, traditional liquidity ratios, cash flow ratios, statement of cash flow, cash basis

\section{Purpose of the Study}

The Purpose of this study is to examine the liquidity of the pharmaceutical companies in Jordan using the cash flow ratios as compared to the traditional ratios.

Liquidity is important to all users of financial statements. Even a very profitable entity will find itself bankrupt if it fails to meet its short-term obligations (Gibson, 2013).

Of the various methods for monitoring liquidity of companies, the common has been the financial ratios (Kirkham, 2012). These ratios include both cash flow ratios (taken from statement of cash flows, and they are prepared according to cash basis), and the traditional ratios (taken from Balance Sheet and income statement, and they are prepared according to the accrual basis).

This paper seeks to compare the findings of some cash flow ratios and traditional ratios in analyzing liquidity of the pharmaceutical companies in Jordan to place much emphasis on the liquidity in this sector and avoid liquidity problems.

\section{Statement of the Problem}

The study seeks to answer the following questions: 
1. Are there any statistical differences between cash flow ratios and traditional ratios in measuring the liquidity of pharmaceutical companies in Jordan?

2. Is evaluation of the liquidity position of the pharmaceutical companies in Jordan only based on the traditional ratios?

3. What is the role of the cash flow in measuring the liquidity position of the pharmaceutical sector in Jordan.

4. Are both cash flow ratios and traditional ratios necessary for liquidity evaluation the pharmaceutical companies in Jordan?

\section{Hypotheses of the Study}

The hypotheses of the study include the following:

H01: There are no statistically differences between cash flow ratio and current ratio as a measure of liquidity in Jordanian Pharmaceutical industries.

H02: There are no statistically differences between critical need cash coverage ratio and quick ratio as a measure of liquidity in Jordanian pharmaceutical industries.

H03: There are no statistically differences between critical need cash coverage ratio and cash ratio as a measure of liquidity in Jordanian Pharmaceutical industries.

H04: There are no statistically differences between cash interest coverage ratio and interest coverage ratio as a measure of liquidity in Jordanian Pharmaceutical industries.

H05: There are no statistically differences between operating cash margin and operating income margin as a measure of liquidity in Jordanian Pharmaceutical industries.

\section{Ratios Used in This Study}

Table 1 presented below compares between cash flow ratios and traditional ratios used in the study and shows their computations

Table 1. Comparison of ratios

\begin{tabular}{|c|c|c|c|}
\hline \multicolumn{2}{|c|}{ Cash Flow Ratios } & \multicolumn{2}{|c|}{ Traditional Ratios } \\
\hline Ratio & Formula & Ratios & Formula \\
\hline (1) & Net operating cash flows & \multirow{2}{*}{$\begin{array}{c}\text { (1) } \\
\text { Current Ratio }\end{array}$} & Total Current Assets \\
\hline $\begin{array}{l}\text { Cash Flow } \\
\text { Ratio }\end{array}$ & Total current liabilities & & Total Current Liabilities \\
\hline \multirow{4}{*}{$\begin{array}{c}(2) \\
\text { Critical } \\
\text { Needs Cash } \\
\text { Coverage }\end{array}$} & \multirow{2}{*}{$\begin{array}{c}\text { Net Operating Cash Flows + } \\
\text { Interest Paid }\end{array}$} & \multirow[t]{2}{*}{ (2a) Quick Ratio } & $\begin{array}{l}\text { Total Current Assets - } \\
\text { Inventories }\end{array}$ \\
\hline & & & Total Current Liabilities \\
\hline & \multirow[t]{2}{*}{$\begin{array}{c}\text { Total Current Liabilities + } \\
\text { Interest Paid }\end{array}$} & \multirow[t]{2}{*}{ (2b) Cash Ratio } & $\begin{array}{c}\text { Cash equivalent }+ \\
\text { Marketable securities }\end{array}$ \\
\hline & & & Total Current Liabilities \\
\hline \multirow{2}{*}{$\begin{array}{c}\text { (3) } \\
\text { Cash Interest }= \\
\text { Coverage }\end{array}$} & $\begin{array}{c}\text { Net Operating Cash Flows }+ \\
\text { Interest }+ \text { Tax }\end{array}$ & \multirow{2}{*}{$\begin{array}{c}\text { (3) } \\
\text { Interest Converge }\end{array}$} & $\begin{array}{c}\text { Net Operating Earnings + } \\
\text { Interest + Tax (EBIT) }\end{array}$ \\
\hline & Annual Interest & & Annual Interest \\
\hline \multirow{2}{*}{$\begin{array}{c}(4) \\
\text { Operating } \\
\text { Cash Margin }\end{array}$} & Net Operating Cash Flows & \multirow{2}{*}{$\begin{array}{c}(4) \\
\text { Operating Income } \\
\text { Margin }\end{array}$} & Net Operating Income \\
\hline & Net Sales & & Net Sales \\
\hline
\end{tabular}

Source: Kirkham, R. 2012, p. 3. 


\subsection{Cash Flow Ratios}

1. Cash Flow Ratio: This ratio measures the company's ability to generate resources to meet its current liabilities.

2. Critical needs Cash Coverage: This ratio measures the company's ability to meet its obligations and pay dividends.

3. Cash interest Coverage: This ratio measures the company's ability to meet interest payments on its entire debt load. Any company with a cash interest coverage less than 1 runs to immediate risk of potential default.

4. Operating Cash Margin or Cash Flow Margin Ratio: This ratio measures the company's performance based on cash generating ability as opposed to profit margin ratio with its focus on accrued based accounting income.

\subsection{Traditional Ratios}

4.2.1 Current Ratio: This ratio shows the relationship between the size of the current assets and current liabilities. The current ratio is considered to be more indicative of short term debt paying ability than the working capital. It measures the overall liquidity position. (Gibson, 2013)

4.2.2 a. Quick Ratio or Acid-test Ratio: This ratio measures the immediate liquidity position. It relates the most liquid assets to current liabilities.

b. Cash Ratio: Sometimes an analyst needs to view the liquidity of a firm from and extremely conservative point of view. For example the company may have pledged its receivables and its inventory, or the analyst suspects severe liquidity problems with inventory and receivables. The best indicator of the company's short-term liquidity may be the cash ratio. The cash ratio indicates the immediate liquidity of the firms. If the cash ratio for the company is too low. This indicates that this company is having immediate problem with paying bills. (Gibson, 2011)

4.2.3 Interest Coverage: This ratio indicates a firm's long-term debt paying ability from the income statement view. A relatively high stable coverage of interest over the years indicate a good record; a low, and fluctuating coverage from year to year indicates a poor record. (Gibson, 2013)

4.2.4 Operating Income Margin: This ratio includes only operating income in the numerator: It gives a measure of net income dollars generated by each dollar of sales. The higher this ratio is the better.

Cash flow ratios are more reliable indicators of liquidity than balance sheet or income statement ratios such as acid-test or current ratio. Balance sheet data are static - measuring a single point of time - While the income statement contains many arbitrary non - cash allocations, such as depreciation and amortization. In contrast, the cash flow statement records the changes in the other statements focusing on what shareholders really care about available cash for operation and investment. Creditors and lenders are using cash flow ratios because these ratios give more information about a company's ability to meet its payment commitments than do traditional balance sheet working capital ratios, such as the current ratio or quick ratio. These traditional ratios indicate how much cash was the company bad available on a single date in the past. Cash flow ratios, on the other hand, test how much cash was generated over a period of time, and compare that to near-term obligations, giving dynamic picture of what resources the company can master to meet its commitment (Mills, and Yamamura, 1998).

The ratios presented in tale (I) focus on the cash flow ratios that share some attributes which are similar to the traditional ratios, and have given names that indicates that similarity. (Kirkham, 2012)

\section{Literature Review \& Previous Studies}

\subsection{Literature Review}

The primary purpose of the statement of cash flows is to provide relevant information about the cash receipt and cash payments of an enterprise during an accounting period in cash and cash equivalents from the following activities: (1) Cash flows from operating activities. (2) Cash flows from financing activities, and (3) Cash flows from financing activities (Schroeder, et al.).

International and Accounting Standard (IAS7) defines operating activities as "the principal revenue - producing activities of the entity and other activities that are not investing or financing, Also, the standard define investing activities as "the acquisition of long-term assets and other investments not included in cash equivalents, and also defines financing activities as "activities that result in changes in size and composition of the contributed equity and borrowings of the entity (IAS 7 paragraph 6). 
Operating cash flows may be reported using either direct method or indirect method. The direct method reports the major classes of gross operating cash receipts (for example, cash collected from customers) and gross operating payments (for example, cash paid to suppliers and employees. Under the indirect method, the same total cash flows from operating activities as under the direct method are ultimately reported, except that the figure is produced by adjusting the profit or loss (IAS 7 paragraph 20).

IAS 7 paragraph 19 encourages, but not requires, reporting entities to use the direct method. This is because the direct method produces a cash flow statement in its purest form with new information that is not otherwise available from income statement and balance sheet (IFRS, Pricewaterhouse Cooper, Accounting Manual, 2012).

The definition of statement of cash flows in the GAAP's statement of financial accounting standard (SFAS) 95- and International Accounting Standard 7, is similar. In both standards the firm is supposed to disclose the total amount and separated items of cash and cash equivalents (Duhovanik, 2008).

Cash is defined as "cash on hand and demand deposit". Cash equivalents are short term highly liquid investments that are needily convertible to known amount of cash (IAS, 7 par. 6).

Net income is the results of changes in assets and liabilities; some current, and some non-current. Consequently, net income cannot be equated with a change in cash. The statement of cash flows discloses the effects of earnings activities on cash resources, how assets were acquired and how they were financed. The ability of an enterprise to generate cash from operations is and important indication of its financial health (Schroeder, et al., 2011). The FASB suggests that the statement of cash flows be used by investors, creditors, and others to assess an enterprises ability to generate future positive net cash flows, and to meet its obligations and pay dividends and its needs for external financing (Carslaw, and Mill, 2001).

The statement of cash flows focuses on liquidity not profitability, since it does not include all revenues and costs, which can be only measured under the accrual method in accounting. Cash flows from operations can give the analyst a better understanding of the quality of earnings. Accrual accounting requires subjective elements in the determination of net income. Estimates, deferrals, allocations, and valuation must be made. Therefore, it is helpful to relate cash from operating activities to net income to interpret its quality. For example, net income may be increasing, yet results in declining cash flow operations. This is a check on net income and a warning to assess the quality of income. For example, accounts receivable or inventory might be increasing rabidly because of growth and expansion. But the increase might also due to collection problems or inability to sell inventory.

\subsection{Previous Studies}

5.2.1 A study by Laitinen, K. (1994) published on line (2006), entitled "Traditional Versus Operating Cash flow in Failure Prediction". The purpose of this study is to analyze the behavior of failing and nonfailing firms in terms of accruals and deferrals (adjustment entries) to show the distinctive nature of the ratios. The empirical results show that traditional cash flow is a more stable and reliable predictor of failure than operating cash flow.

5.2.2 Jones and Widjaja (1998) conducted a study entitled "The Decision of Cash-Flow Information", the results of this study are based on a survey of 159 financial statement users, of which 83 were loan officers (LO) and 76 were financial analysts (FA) in Australia. The overall results indicate strong support for the cash flow statement (CFS) by those user groups. This study indicates that LOS and FAs rate both the CFS and others financial statements to have high degree of relevance of the purposes of making and evaluating commercial loan/investment decisions. It is noteworthy that LOS and FAs rated the relevance of the CFS reasonably highly across most of the specified decision contexts.

Statistical analysis of the data collected revealed that LOS rated prediction functions of the CFs relatively more highly than all other decision categories. This was followed by (in order of importance) rating of liquidity and solvency evaluation, capacity to adopt to changed conditions, monitoring functions and performance evaluation.

Similar statistical procedures revealed that FAs rated decision contexts differently from LOS. FAs. Rated liquidity and solvency evaluation as the most important decision category of the CFS. This was followed by (in order of importance) ratings of: prediction functions, monitoring functions, performance evaluation and capacity to adapt to changed conditions.

In general, some important conclusions emerge from this study. First, it is noteworthy that liquidity and solvency, and prediction functions were rated as the two most important functions of CFS by both LOS and FAs, second, FAs appear to be an equally significant, if not greater user of the CFS than LOS. (Jones, and Widgaja, 1998). 
5.2.3 Another study by Jones (1998) compares decision usefulness ratings of the CFS with profit and loss statement (PLS) and balance sheet (BS) across a wide range of decision contexts.

The results of this study indicated that the loan officers and financial analysis rated a CFS, prepared under direct method, to have a number of performance evaluation, and monitoring contexts, and greater decision-making relevance a cross a number of liquidity and solvency and prediction evaluation functions.

5.2.4 A study by Jooste, L. (2007), entitled "An Evaluation of the usefulness of Cash Flow Ratios to predict financial distress." The purpose of this study is to outline the general relashinship between failed and nonfailed entities using cash flow ratios in South Africa. The results of this study indicate that the higher the ratio, calculated from cash flow statement, the lower the likelihood of failure, and a positive ratio also indicates positive cash flows. The failed entities have lower cash flows than nonfailed entities and smaller reserves of liquid assets.

5.2.5 A study by Qin, Xuezhi \& Pastory, D. (2012) entitled "Comparative Analysis of Commercial Banks Liquidity Position: the case of Tanzania." This study gives an overview picture of commercial banks liquidity position in Tanzania for the period of ten years (2000-2009). The ratios used to measure the strength of liquidity position in commercial banks include the following: Total deposits to core funding, liquid assets to demand liabilities, and gross loans to total deposits. The finding revealed that commercial banks under study have strong liquidity position.

5.2.6 A study by Dwolabi, S. \& Obida, S. (2012) entitled "Liquidity Management and Corporate Profitabilities": Case study of selected Manufacturing Companies listed in Nigerian Stock Exchange".

This study concluded that liquidity management especially at the wake of the global financial crisis, has become a major source of concern for business managers. Effective cash optimization is critical to all organizations. An organization having a proper set of liquidity management policies and procedures will improve profits, reduce the risk of corporate failure, and significantly improve its chances of survival. The study has shown relevance degree of relationship between liquidity management and profitability.

5.2.7 A study by Armen, stepanyan (2013) entitled "Performance Assessment of Major U.S. Airlines via Cash Flow Ratios". This study conducted cash flow analysis for major U.S. Airlines. The result of this analysis shows that airlines Companies have liquidity problems. The U.S. Airlines have difficulties in generating cash to fully cover unavoidable expenditures and current liabilities.

The corruption of cash flow ratios, such as: adequacy ratio, cash to total debt ratio, and total free cash ratio that evaluate the company's viability as a going concern indicates that U.S. airlines are likely to face financial difficulties when it comes to meet future ongoing operational and financial commitments. Difficulties in generating sufficient cash flow result from slowly growing demand for air travels, increasing operating expresses mainly driven by continuously rising fuel prices and high labor cost, specially U.S. airlines financial condition and operations were highly affected by recent economic crisis began in late 2007 in the United States.

5.2.8 A study by Prowal, H.K., and Jain, S. (July - December, 2013) entitled "cash flow ratios to predict investment's soundness". The purpose of this study is to show how cash flow ratios try to override limitations concerning conventional ratios. The authors of this study believe that for successful operation of a company, the company should generate enough cash to meet daily operation expenses, repay the loans, purchase assets, pay taxes and dividend.

This study tests significance of cash flow ratios in evaluating performance of a company and use them to differentiate a sound from a risky firms for investment. Cash Flow Ratios, by the way of showing true picture of a company, immensely help all the stakeholders in evaluating the worth of a company. This study through listing down various merits of cash flows ratios has tried to prove how these ratios are significant for better corporate governance. After discriminate analysis was conducted on 14 cash flow ratios to find their impact, three ratios: cash from operations/capital employed, cash flow from operations/debt issued, and cash from operations/total debt were found to be most significant.

5.2.9 A study by Nyabwarga, R.N., Dr.Ogera, P., and Nyakurdi, F. (2013), entitled "An Empirical Analysis of the liquidity, solvency, and financial Health of Small and Medium Sized Enterprises in kisii municipality, Kenya,". The purpose of this study was to carry out a financial diagnosis of small and medium enterprises (SMES) financial performance by focusing on their liquidity. Solvency, and profitability positions using ratio analysis. Data for the study covered the period (2009-2011), and was obtained from financial statements of a sample of SMEs. The findings of the study showed that the liquidity position of SMEs, their solvency and financial health were low. Also, the result of the study show that there is a significant impact of current ratio, quick ratio and debt to total assets on return on assets (ROA). The recommendations of this study include that liquidity, solvency, and financial health of SMEs should be an integral part of their policy frameworks. 


\section{Liquidity Ratios}

The concept of cash flow is different from the concept of net income, and the user of accounting information should think of each in different terms and analyze each from different perspective. Cash flow analysis use ratios that focus on cash flow and how solvent liquid and viable the company is. The Following are some important cash flow ratios that can be used in economic decisions with their calculations and interpretations.

\subsection{Cash Coverage Ratios}

These ratios include the following:

6.1.1 Cash Interest Coverage $=$

CFFO (cash flow from operation) + cash payments for interest + income tax

Cash payments for interest

Source: Mills \& Yamamura, 1998.

A traditional time - interest earned ratio does not offer a useful benchmark for debt service because of the non - cash items and accrual adjustments required for determining reported earnings. By contrast, the cash interest coverage ratio with its emphasis on cash flows provides a more realistic indicator of liquidity, and an organization's ability to service its debt. A very low ratio signifies an increased risk that a company might not have enough cash available to meet its obligation to pay interest on its debt. Therefore, it is important to monitor and track trends in the interest coverage ratio overtime.

\subsubsection{Cash Long-term Debt Coverage $=$}

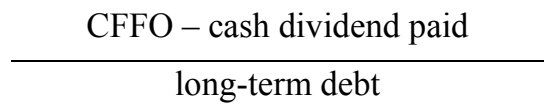

Source: Mills \& Yamamura, 1998.

The long-term debt coverage ratio measures the solvency of a company by indicating the time it would take to pay back debts.

\subsubsection{Cash Current Liability Coverage $=$}

CFFO - cash dividends paid

Source: Mills \& Yamamura, 1998

This ratio is a better indicator of a company's actual ability to meet current liabilities in a given year from its operations more than widely known ratios such as the current ratio and quick ratio. This ratio is a liquidity ratio.

\subsubsection{Cash Dividend Coverage $=$}

$\mathrm{CFFO}$ - preferred dividends

Source: Carlaws \& Mills, 2001.

$$
\text { Common Stock Dividends }
$$

This ratio provides evidence of the ability of the company to meet current dividends from normal operating cash flows.

\subsection{Quality of Income}

Statement of cash flows could assist users of accounting information in determining reasons for differences between net income and associated cash receipts and payments. The reasons for these differences provide a basis for evaluating the quality of income. The measurement of cash flows is perceived as being more reliable and more objective than the measurement of income because the latter involves more judgment about accruals, allocations, and valuation (Carslow, and Mills, 2001).

\subsubsection{Quality of Income Ratio}

$=\frac{\text { CFFO }+ \text { cash payments for interest }+ \text { income tax }}{\text { Net Income }+ \text { Interest Expense }+ \text { Income Tax }}$

Source: Urbancic, Frank, 2002.

The quality of income ratio is intended to provide an indication of the variance between cash flows and reported earnings. Reported earnings; in many cases include income, such as installment sales, or expenses, such as depreciation, which do not have a current cash impact. 


\subsubsection{Capital Expenditure Ratio (Capital asset Ratio)}

$$
=\frac{\text { CFFO }+ \text { cash inflows from capital Asset disposals }}{\text { Cash outflows for capital asset acquisition }}
$$

Source: Mills \& Yamamura, 1998.

A company's cash generating ability must be capable not only of meeting its obligations but also of financing capital expenditures.

The capital asset ratio shows a company's ability to meet its capital expenditure needs from cash generated by operating activities rather than from financing activities. A ratio of 1.00 or greater means that debt financing is not necessary for capital expenditures.

\subsection{Cash Rate of Returns Ratios (Cash Flow Returns)}

\subsubsection{Cash Flow Per Share $=$}

CFFO - cash paid for preferred dividend

Weighted Average Outstanding Common Stock

Source: Urbancic, Frank, 2002.

This ratio shows the operating cash flow attributable to each common share. The investors can compare the cash dividend coverage and cash flow per share.

6.3.2 a. Cash return on Assets $=$

CFFO before interest and tax

Total Assets

b. Cash return on equity $=$

CFFO before interest and tax

Stockholders' equity

Source: Carslaw \& Mill, 2001.

Stockholders' equity

The above two cash rate of return ratios on assets and equity provide guidance on the enterprise's ability to generate superior future cash flows from invested funds.

6.4 Operating Cash Margin=

CFFO

Net Sales

Source: Urbancic, Frank, 2002.

This ratio measures the ability of a firm to translate sales into cash. This ratio expresses the relationship between cash generated from operations and net sales. The higher this ratio is the better. The operating cash margin ratio provides a good indicator of performance based on cash generating ability as opposed to profit margin ratio with its focus on accrual based accounting income. This ratio can prove useful in evaluating cash management performance, as well as, credit granting policies and receivable collections. (Urbancic, F., 2002)

\subsection{Price/Cash Flow Ratio $=$}

Share Price

Source: Mills \& Yamamura, 1998.

Operating cash flow per share

Share price is usually the closing price of the stock on a particular day and operating cash flow is taken from the statement of cash flow. This ratio is often considered a better indication of the company's value than the price to earnings ratio.

The presentation of cash-flow data is necessary to evaluate the firms liquidity, solvency, and financial flexibility. Liquidity is the firms ability to convent an asset to cash to pay a current liability. It is referred to as the "nearness" to cash of an entity's economic resources and obligations. Liquidity information is important to users in evaluating the timing of future cash flows, it is also necessary to evaluate solvency and financial flexibility.

\section{Research Methodology}

This research involved the comparison between the traditional ratios and cash flow ratios of seven pharmaceutical companies in Jordan, over six years (2007-2012). These companies are from the same pharmaceutical industry, and 
they represent $90 \%$ of this industry. The data was taken from the annual reports of these companies. The financial statements used in calculating the ratios are prepared according to the International Accounting Standards, and they are also audited according to the International Standard on Auditing (ISA) applied in Jordan.

The ratios used to examine the liquidity of the pharmaceutical companies are presented in Table 1.

\section{Analysis of Results of Study}

The analysis of the study is done in two methods. These methods are discussed below:

\subsection{Method 1}

The ratios are presented on a company by company basis, as shown in tables $2-8$, given that they are seven companies and the ratios are calculated for six years (2007-2012). The comparative analysis is concerned with indentifying trends and indication of differences between cash flow ratios and traditional ratios as explained in the comments shown at the end of each table. The tables and comments are as follows:

Table 2. Liquidity ratios

(Hekma Pharmaceutical)

\begin{tabular}{|c|c|c|c|c|c|c|}
\hline Cash Flow Ratios & 2007 & 2008 & 2009 & 2010 & 2011 & 2012 \\
\hline Cash flow ratio & 0.0144 & 0.1107 & 0.6503 & 0.6273 & 0.7832 & 0.7104 \\
\hline \multicolumn{7}{|l|}{ Critical needs cash } \\
\hline Coverage & 0.0144 & 0.1107 & 0.6503 & 0.6273 & 0.7832 & 0.7104 \\
\hline Cash interest coverage & 1.2114 & 1.3337 & 9.6558 & 10.8897 & 19.2059 & 11.6128 \\
\hline Cash margin & 0.0036 & 0.0355 & 0.1884 & 0.1846 & 0.2729 & 0.2215 \\
\hline \multicolumn{7}{|l|}{ Traditional Ratios } \\
\hline Current Ratio & 1.5778 & 1.4515 & 1.8665 & 1.6732 & 1.3337 & 2.2302 \\
\hline Quick Ratio & 0.9169 & 0.9359 & 1.2913 & 1.1007 & 0.9205 & 1.652 \\
\hline Operating Cash Ratio & 1.3291 & 1.1696 & 1.4225 & 1.4154 & 1.2086 & 1.463 \\
\hline Interest Coverage & 6.4108 & 7.3129 & 10.0664 & 1.1904 & 19.4935 & 1.9745 \\
\hline Operating Income Margin & 0.1984 & 0.2067 & 0.1977 & 0.1638 & 0.2655 & 0.1891 \\
\hline
\end{tabular}

Comment: In this company, cash flow ratios show a weaker short-term liquidity position for the years $2007-2012$, specially in $2007 \& 2008$ than is indicated by traditional ratios. Cash interest coverage ratios are less than interest coverage for years 2007, 2008, 2009, and higher in 2010, and much higher in 2012. This result indicates that the company has available cash to pay the annual interest. Operating cash margin ratio are less than operating income margin during the years 2007, 2008, and 2009. But, the cash margin ratios started to be more than operating income margin. This indicates that company is improving during the years 2010, 2011 and 2012.

Table 3. Liquidity ratios

(United Company for Pharmaceutical Industry)

\begin{tabular}{|c|c|c|c|c|c|c|}
\hline Cash Flow Ratios & 2007 & 2008 & 2009 & 2010 & 2011 & 2012 \\
\hline Cash flow ratio & 0.1451 & 1.4362 & 0.0041 & 0.2435 & 0.0061 & 0.0099 \\
\hline \multicolumn{7}{|l|}{ Critical needs cash } \\
\hline Coverage & 0.1451 & 1.4362 & 0.0041 & 0.2435 & 0.0061 & 0.0077 \\
\hline Cash interest coverage & 2.9406 & 3.957 & 0.1375 & 9.3787 & 0.4528 & 0.2949 \\
\hline Cash margin & 0.1258 & 0.1524 & 0.0054 & 0.2321 & 0.0053 & 0.0067 \\
\hline \multicolumn{7}{|l|}{ Traditional Ratios } \\
\hline Current Ratio & 1.4323 & 1.3118 & 1.3483 & 1.5385 & 1.699 & 1.3983 \\
\hline Quick Ratio & 1.2538 & 0.768 & 0.6917 & 0.9139 & 0.9304 & 0.9607 \\
\hline Operating Cash Ratio & 1.4239 & 1.2952 & 1.3357 & 1.5352 & 1.6958 & 1.3825 \\
\hline Interest Coverage & 1.2753 & -0.2642 & 2.3743 & 1.9181 & 77.4475 & 48.3701 \\
\hline Operating Income Margin & -0.1534 & -0.0189 & 0.063 & 0.0205 & 0.0549 & 0.0493 \\
\hline
\end{tabular}


Comment: in this company, cash flow ratios show stronger liquidity position than is indicated by traditional ratios. Cash flow ratios for the years 2007 and 2008 are higher than the current ratios for the same two years. This means that liquidity position of the company is strong and the company can pay its obligations. Then, cash flow ratios began to be lower than current ratios during the years 2009, 2010, 2011, 2012. The liquidity position of the company became very weak in years 2011 and 2012.

Cash interest coverage is below 1 in years 2009, 2011 and 2012. This indicates a liquidity risk of the company. But the interest coverage ratios is high in 2011 and 2012. This indicates the strong ability of the company to pay its interest from the income statement view. These ratios were 77.4 in 2011, and 48.3 in 2012.

The cash margin ratios indicate that company's performance based on cash is higher than operating income margin based on accounting income in years 2007, and 2008, but, they are lower from years 2009-2012: The operating income margin ratios is improving from year 2007 to year 2009. This is a good indicator of the success of the company.

Table 4. Liquidity ratios

(Philadelphia Company for Pharmaceutical Industry)

\begin{tabular}{|c|c|c|c|c|c|c|}
\hline Cash Flow Ratios & 2007 & 2008 & 2009 & 2010 & 2011 & 2012 \\
\hline Cash flow ratio & -0.0305 & -0.2463 & -0.2005 & 0.0243 & -0.3409 & 0.2217 \\
\hline \multicolumn{7}{|l|}{ Critical needs cash } \\
\hline Coverage & -0.0305 & -0.2463 & -0.2005 & 0.0243 & -0.3409 & 0.2217 \\
\hline Cash interest coverage & 1.7856 & 3.4817 & -9.5168 & 1.9594 & 7.9241 & 4.5838 \\
\hline Cash margin & -0.0195 & 0.0778 & -0.0476 & 0.0138 & -0.2879 & 0.248 \\
\hline \multicolumn{7}{|l|}{ Traditional Ratios } \\
\hline Current Ratio & 1.9061 & -0.2005 & 5.7442 & 2.5034 & 1.8046 & 1.4381 \\
\hline Quick Ratio & 1.2152 & 3.7441 & 3.4459 & 1.5433 & 1.1119 & 0.8685 \\
\hline Operating Cash Ratio & 1.785 & 2.462 & 5.1594 & 2.1629 & 1.7785 & 1.3148 \\
\hline Interest Coverage & 6.4991 & 1.9394 & -8.5168 & 1.9594 & -2.2066 & -5.1275 \\
\hline Operating Income Margin & 0.1333 & 0.0429 & -0.1025 & -0.2587 & -0.1333 & -0.4241 \\
\hline
\end{tabular}

Comment: In this company, cash flow ratios show weaker liquidity position than is indicated by the traditional ratios. The current ratios range, during the six years of the study, was between 1-1.6 times. This range measures the overall liquidity position of the company. The cash interest coverage is more than (1) except in year 2009. This indicates that the company has a good ability to meet its interest payments on its entire debt load. In contrast, the interest coverage ratio based on accrual basis is low and fluctuating during the six years. This indicates a poor record.

The cash margin \& the operating income ratios are low during the year 2007-2012. This shows the weakness of the company in generating cash from sales. According to these ratios the company suffers from liquidity problems.

Table 5. Liquidity ratios

(Middle East Company for pharmaceutical Chemical \& Medical Equipment Industry)

\begin{tabular}{|c|c|c|c|c|c|c|}
\hline Cash Flow Ratios & 2007 & 2008 & 2009 & 2010 & 2011 & 2012 \\
\hline Cash flow ratio & -0.0711 & 0.0291 & 0.0847 & 0.028 & 0.0677 & -0.022 \\
\hline \multicolumn{7}{|l|}{ Critical needs cash } \\
\hline Coverage & -0.0711 & 0.0291 & 0.0847 & 0.028 & 0.0677 & -0.022 \\
\hline Cash interest coverage & 0.4509 & 5.1991 & 2.737 & 1.6068 & 2.2033 & -1.044 \\
\hline Cash margin & 0.0782 & 0.0309 & 0.0909 & 0.0328 & 0.1849 & -0.0049 \\
\hline \multicolumn{7}{|l|}{ Traditional Ratios } \\
\hline Current Ratio & 1.1477 & 1.063 & 0.9914 & 1.0624 & 0.7934 & 0.789 \\
\hline Quick Ratio & 1.0932 & 0.638 & 0.568 & 0.6719 & 0.4529 & 0.5439 \\
\hline Operating Cash Ratio & 1.0884 & 1.0137 & 0.9301 & 1.0016 & 0.712 & 0.7189 \\
\hline Interest Coverage & 1.5215 & 1.3198 & 1.9555 & 1.7256 & -5.6195 & -2.0843 \\
\hline Operating Income Margin & 0.0281 & 0.0137 & 0.05 & 0.0392 & -0.7099 & -0.1223 \\
\hline
\end{tabular}

Comment: In this company, cash flow ratios \& the current ratios and quick ratios indicate that the company liquidity positions is weak. For example, the current ratio in 2012 is 0.789 while cash flow ratio for the same year is (-022). 
The cash flow ratios show a weaker liquidity position than indicated by traditional ratio. The cash interest coverage ratios show a better ability of the company than the traditional ratio. The cash margin ratios show stronger cash generating ability of company than operating income margin.

Table 6. Liquidity ratios

(Dar Al-Dawa Company for Development \& Investment)

\begin{tabular}{|c|c|c|c|c|c|c|}
\hline Cash Flow Ratios & 2007 & 2008 & 2009 & 2010 & 2011 & 2012 \\
\hline Cash flow ratio & 0.2918 & 0.0325 & 0.0448 & 0.1329 & 0.12 & 0.4031 \\
\hline \multicolumn{7}{|l|}{ Critical needs cash } \\
\hline Coverage & 0.2918 & 0.0325 & 0.0448 & 0.1329 & 0.12 & 0.4031 \\
\hline Cash interest coverage & 16.4973 & 1.7269 & 3.798 & 2.0996 & 3.1092 & 8.447 \\
\hline Cash margin & 0.0958 & 0.0135 & 0.0318 & 0.1202 & 0.0876 & 0.3023 \\
\hline \multicolumn{7}{|l|}{ Traditional Ratios } \\
\hline Current Ratio & 3.8044 & 2.6881 & 1.9584 & 1.8832 & 2.0777 & 1.8777 \\
\hline Quick Ratio & 2.9857 & 1.8917 & 1.431 & 1.3674 & 1.518 & 1.5565 \\
\hline Operating Cash Ratio & 3.4538 & 2.2694 & 1.7285 & 1.3819 & 1.4586 & 1.3959 \\
\hline Interest Coverage & 1.7184 & 10.5668 & 11.6417 & 7.9717 & 4.3978 & 3.0682 \\
\hline Operating Income Margin & 0.1077 & 0.0948 & 0.1409 & 0.2044 & -0.1418 & 0.0827 \\
\hline
\end{tabular}

Comment: In this company, the cash flow ratios show a weaker liquidity position than is indicated by the traditional ratios. The cash interest coverage ratios in years 2007, and 2012 are higher than interest coverage ratios. This shows that the cash position is strong in these two years, and the company has a good ability to pay its obligations.

Table 7. Liquidity ratios

(Arab Company for Pharmaceutical Industry)

\begin{tabular}{|c|c|c|c|c|c|c|}
\hline Cash Flow Ratios & 2007 & 2008 & 2009 & 2010 & 2011 & 2012 \\
\hline Cash flow ratio & -0.1327 & 1.4371 & 0.1181 & 0.1738 & 1.5558 & 0.5297 \\
\hline \multicolumn{7}{|l|}{ Critical needs cash } \\
\hline Coverage & -0.1327 & 1.4371 & 0.1181 & 0.1738 & 1.5558 & 0.5297 \\
\hline Cash interest coverage & -9.1286 & 21.1356 & 8.2738 & 30.0042 & 26.9299 & 8.9596 \\
\hline Cash margin & -0.0886 & 0.3811 & 0.2815 & 0.3422 & 0.4416 & 0.1767 \\
\hline \multicolumn{7}{|l|}{ Traditional Ratios } \\
\hline Current Ratio & 2.1833 & 3.5249 & 3.941 & 3.7965 & 2.2696 & 1.938 \\
\hline Quick Ratio & 1.1402 & 2.6254 & 3.1738 & 3.0129 & 1.6799 & 1.4347 \\
\hline Operating Cash Ratio & 2.0514 & 2.863 & 3.2567 & 3.0957 & 1.7315 & 1.581 \\
\hline Interest Coverage & 17.9796 & 12.5066 & 81.4179 & 20.9234 & 10.4858 & 6.4377 \\
\hline Operating Income Margin & -0.2079 & 2.2085 & 0.197 & 0.2323 & 0.1574 & 0.1146 \\
\hline
\end{tabular}

Comment: In this Company, the cash flow ratios show a weaker liquidity position than is indicated by traditional ratios. Except the interest coverage, for example the cash interest coverage ratio was 21.1 in year 2008, and 30.004 in year 2010, while, the interest coverage ratios for the same years $2007 \& 2010$ are $12.5 \& 20.92$ times respectively.

Table 8 . Liquidity ratios

(Amman Company for Pharmaceuticals and Trading)

\begin{tabular}{|c|c|c|c|c|c|c|}
\hline Cash Flow Ratios & 2007 & 2008 & 2009 & 2010 & 2011 & 2012 \\
\hline Cash flow ratio & -0.0723 & 0.0542 & 0.1964 & 0.1793 & 0.0367 & -0.2674 \\
\hline \multicolumn{7}{|l|}{ Critical needs cash } \\
\hline Coverage & -0.723 & 0.0542 & 0.1964 & 0.1793 & 0.0367 & -0.2674 \\
\hline Cash interest coverage & 6.5418 & 3.6528 & 20.3316 & 3.6379 & 4.9096 & 14.1493 \\
\hline Cash margin & -0.0315 & 0.0226 & 0.0887 & 0.0008 & 0.0159 & -0.1117 \\
\hline \multicolumn{7}{|l|}{ Traditional Ratios } \\
\hline Current Ratio & 1.3908 & 1.3871 & 1.3702 & 1.4406 & 1.5366 & 1.6906 \\
\hline Quick Ratio & 0.6319 & 0.746 & 0.6567 & 0.7339 & 0.9194 & 1.0258 \\
\hline
\end{tabular}




\begin{tabular}{lcccccc}
\hline Operating Cash Ratio & 1.2898 & 1.243 & 1.2584 & 1.355 & 1.4636 & 1.5665 \\
\hline Interest Coverage & 7.7972 & 5.8107 & 8.3556 & 9.298 & 14.6779 & 9.1304 \\
\hline Operating Income Margin & 0.0425 & 0.0447 & 0.037 & 0.0573 & 0.0827 & 0.0765 \\
\hline
\end{tabular}

Comment: In this Company, the cash flow ratios show a weaker liquidity position than is indicated by the traditional ratios except for the interest coverage ratios for the years $2009 \& 2012$. The cash interest coverage ratios are higher than interest coverage ratios (traditional ratios). This indicates that the company ability to pay its interest is stronger in these two years. Besides the interest coverage ratios are high which indicates a good record for the company.

\subsection{Method 2}

\subsubsection{Statistical Analysis \& Testing the Hypotheses}

Cash flows ratios and traditional ratios are calculated using the information of the financial statements of seven companies for six years (2007-2012). Then these ratios are compared with the standard ratios of the pharmaceutical industry. A score of 1 is given to the ratios of the company that is equal or more than industry ratio, and a score of zero is given to the ratio of the company that is less than the industry ratio. The mean for number of times where the ratios are equal or more than the industry ratios is calculated. The SPSS program is used and the independent sample t-test is applied to test the significant differences between cash flow ratios and traditional ratios to measure liquidity of pharmaceutical companies in Jordan and test the hypotheses.

\subsubsection{Hypotheses Testing}

To test research hypotheses independent sample t-test had been applied, the results were as follows:

H01: There are no statistically differences between cash flow ratio and current ratio as a measure of liquidity in Jordanian Pharmaceutical industries.

Table 9. Testing H01

\begin{tabular}{lccccc}
\hline Measure & Mean & St.dev & Mean Diff. & t-value & Sig. \\
\cline { 1 - 3 } Cash Flow Ratio & 0.6190 & 0.4915 & \multirow{2}{*}{0.26190} & 2.458 & \multirow{2}{*}{0.016} \\
\cline { 1 - 3 } Current Ratio & 0.3571 & 0.4850 & & & \\
\hline
\end{tabular}

Table 9 reports that the mean differences between cash flow ratio and current ratio is $(0.26190)$ towards cash flow ratio, the significance value of the $t$ statistic $(t=2.458)$ is $(\mathrm{Sig}=0.016)$ less that 0.05 , which means that the difference is significant.

H02: There are no statistically differences between critical need cash coverage ratio and quick ratio as a measure of liquidity in Jordanian pharmaceutical industries.

Table 10. Testing H02

\begin{tabular}{lccccc}
\hline Measure & Mean & St.dev & Mean Diff. & t-value & Sig. \\
\cline { 1 - 3 } Critical need coverage ratio & 0.6190 & 0.4915 & 0.3333 & \multirow{2}{*}{3.218} & \multirow{2}{*}{0.002} \\
\cline { 1 - 2 } Quick Ratio & 0.2857 & 0.4572 & & & \\
\hline
\end{tabular}

Table 10 reports that the mean differences between critical need cash coverage ratio and quick ratio is $(0.3333)$ towards critical need cash coverage ratio, the significance value of the $t$ statistic $(t=3.218)$ is $(\mathrm{Sig}=0.002)$ less than 0.05 , which means that the difference is significant.

H03: There are no statistically differences between critical need cash coverage ratio and cash ratio as a measure of liquidity in Jordanian pharmaceutical industries.

Table 11. Testing H03

\begin{tabular}{lccccc}
\hline Measure & Mean & St.dev & Mean Diff. & t-value & Sig. \\
\hline Critical need coverage ratio & 0.6190 & 0.4915 & \multirow{2}{*}{0.07143} & 0.658 & \multirow{2}{*}{0.513} \\
\cline { 1 - 3 } Cash Ratio & 0.5476 & 0.538 & & & \\
\hline
\end{tabular}

Table 11 reports that the mean differences between critical need cash coverage ratio and cash ratio is $(0.07143)$ towards critical need cash coverage ratio, the significance value of the $(\mathrm{t})$ statistic $(\mathrm{t}=0.658)$ is $(\mathrm{Sig}=0.513)$ greater than 0.05 , which means that the difference is not significant. 
H04: there are no statistically differences between cash interest coverage ratio and interest coverage ratio as a measure of liquidity in Jordanian Pharmaceutical industries.

Table 12. Testing H04

\begin{tabular}{|c|c|c|c|c|c|}
\hline Measure & Mean & St.dev & Mean Diff. & t-value & Sig. \\
\hline Cash interest coverage ratio & 0.7619 & 0.4311 & \multirow{2}{*}{0.09524} & \multirow{2}{*}{0.960} & \multirow{2}{*}{0.340} \\
\hline Interest coverage Ratio & 0.6667 & 0.4771 & & & \\
\hline
\end{tabular}

Table 12 reports that the mean differences between cash interest coverage ratio and interest coverage ratio is $(0.09524)$ towards cash interest coverage ratio, the significance value of the $t$ statistic $(\mathrm{t}=0.960)$ is $(\mathrm{Sig}=0.340)$ greater than 0.05 , which means that the difference is not significant.

H05: There are no statistically differences between operating cash margin and operating income margin as a measure of liquidity in Jordanian pharmaceutical industries.

Table 13. Testing H05

\begin{tabular}{|c|c|c|c|c|c|}
\hline Measure & Mean & St.dev & Mean Diff. & t-value & Sig. \\
\hline Operation cash margin & 0.4048 & 0.4968 & \multirow{2}{*}{-0.02381} & \multirow{2}{*}{-0.219} & \multirow{2}{*}{0.827} \\
\hline Operating income margin & 0.4286 & 0.5009 & & & \\
\hline
\end{tabular}

Table 13 reports that the mean differences between operating cash margin and operating income margin is (-0.02381) towards operating income margin, the significance value of the $t$ statistic $(t=00.219)$ is $(\mathrm{Sig}=0.827)$ greater than 0.05 , which means that the difference is not significant.

\section{Conclusion}

The findings of this study indicated that there are significant differences between some cash flow ratios and some traditional ratios, such as cash flow ratios and current ratio. Also, it was found that there are no significant differences between other cash flow ratios and traditional ratios such as cash interest coverage ratio and interest coverage ratio.

Cash flow ratios are more effective measures of liquidity than traditional ratios because cash flow ratios give more information about the company's ability to meet its commitment. In addition, both types of ratios, cash flow ratios and traditional ratios should be used together to reach to a comprehensive conclusion about the liquidity position of the company. The study showed that the liquidity position of the Jordanian pharmaceutical companies is average. The statistical analysis showed that out of 378 ratios used in the study for seven companies and six years, there are (196) ratios got a score of 1 , which means that these ratios are equal or more than the pharmaceutical industry ratio. In percentage, $52 \%$ of the ratios of the companies under study are equal or more than the industry ratio. Forty eight percent of the companies' liquidity ratios are under the liquidity ratio of the pharmaceutical industry in Jordan.

\section{References}

Armen, Stempanyan. (2013, December). Performance Assessment of Major U.S. Airlines via Cash Flow Rations. Journal of the Faculty of Economics, University of Oradea, I(2), 398-468.

Bahnson, B., Miller, P., \& Budge, B., (1996). Nonarticulation in Cash Flow Statements and Implications for Education, Research and Practice. Accounting Horizons, (AAA), 10(4). 1-15.

Carslaw, C., \& Mills, J., (2001, November). Developing Ratios for Effective Cash Flow Statement Analysis. Journal of Accountancy, 63-70.

Duhovnik, Metka. (2008). Improvements of the Cash Flow Statement Control Function in Financial Reporting. Zb.rad, fak Rij, 26(2), 123-150.

Dwolabi, S.A., \& Obida, S.S. (2012, August). Liquidity Management and Corporate profitability: Case Study of Selected Manufacturing Companies Listed on the Nigerian Stock Exchange. Business Management Dynamics, $2(2), 10-25$.

Gibson, C. (2013). Financial Reporting and Analysis Using Financial Accounting Information (Thirteenth ed.). South Western. Cengage Learning.

Hamman, W. (1994). Cash Flow Ratios-Investments Basics. Investment Analysis Journal, (38), Summer, 4-53.

International Accounting Standard Board. (2012). A Guide through International Financial Reporting Standards. 
London: International Accounting Standards Committee Foundation.

Jones, S., \& Widjaja, L. (2000). The Decision Relevance of Cash Flow. ABACUS, 34(2), 204-219.

Jooste, L. (2007). An Evaluation of the Usefulness of Cash Flow Ratios to Predict Financial Distress. Acta Commercii. Co. za., 1-12.

Kirkham, R. (2012). Liquidity Analysis Using Cash Flow Ratios and Traditional Ratios: The Telecommunications Sector in Australia. Journal of New Business Ideas and Trends, 10(1), 1-13.

Latinen, E. K. (1994, March). Traditional Versus Operating Cash Flow in Failure Prediction. Journal of Business Finance and Accounting, 21(2), 195-217.

Mills, J., \& Yamamura, J. (1998). The power of Cash Flow Ratio. Journal of Accounting, 186(4), 53-61.

Nyabwang, R.N., Dr. Djera, P. Otieno. S., \& Nyakundi, F. N. (2013). An Empirical Analysis of liquidity, Solvency, and Financial Health of Small and Medium Sized Enterprises in Kissi Manicipality, Kenya. European Journal of business and Management, 5(8), 1-16.

Parnal, H.K. of Jain, shashank. (2013, July-December). Cash Flow Ratios to Predict Investment's Soundness. AsiaPacific Finance and Accounting Review, 55-76.

Pricewaterhouse Coopers LIP. (2012). Manual of Accounting-IFRS. Great Britain, Bloomsbury Professional.

Qin, Xuezhi, \& Pastory, Dickory, Dickson. (2012, May). Comparative Analysis of Commercial Banks Liquidity Position: the Case of Tanzania. International Journal of business and Management, 7(10), 134-141.

Schroeder, R., Clark, \& Cathey J. (2011). Financial Accounting Theory and Analysis: Text and Cases (10 ${ }^{\text {th }}$ ed.). John Wiley \& Sons Inc.

Urbancic, F. (2002). The Power of Cash Flow Ratios. New Accounting/USA.com. 